\title{
Quranic Concept of Halalan Tayyiban and its Application in Food and Beverages of Hospitality Sector in Malaysia
}

\author{
Amiratul Munirah Yahaya ${ }^{1^{*}}$, Zulaipa Ruzulan ${ }^{1}$ \\ ${ }^{1}$ Academy of Contemporary Islamic Studies, Universiti Teknologi MARA, \\ 40450 Shah Alam, Selangor, Malaysia \\ ${ }^{*}$ Corresponding Author \\ amiratul@uitm.edu.my
}

Received: 4 September 2020

Accepted: 10 September 2020

Online First:

\begin{abstract}
Halal hospitality services have been increasing year by year due to the demand from Muslims for halal food and beverages. With this development, there is a need to ensure that the halal food providers are well-equipped enough with halal knowledge in order to ensure Muslim consumers obtain halal food in the best manner. This is because malpractice could happen if the practitioners are having lack of knowledge on halal related matter. In relation to this, this article aims to discuss the Quranic concept of halalan tayyiban and its application in food and beverage in the hospitality sector in Malaysia. Firstly, the study aims to examine the Quranic principles of halalan tayyiban. Secondly, it takes into account to what extent that these Quranic principles are applied in the hospitality sector of Malaysia, hence, these principles are examined and analysed accordingly. The methods of data collection involved library research and in-depth interview with hospitality skills trainer. The technique of analysis used was content analysis. Data related to the study were analysed and descriptive data using percentages was used. The findings of the study indicated that some hotels are concerned with the Quranic concept of halalan tayyiban and it is applied in serving their food and beverage in order to attract more customers who
\end{abstract}


are particular into taking halalan tayyiban food and beverage for healthy and righteous living.

Keywords: Food and Beverage, Halalan Tayyiban, Hospitality, Quranic Concept.

\section{INTRODUCTION}

There is an increasing concern among Muslim consumers on the questionable status of halal food and beverage in Malaysian hotels. Islam provides clear Quranic principles as guidelines to determine halalan tayyiban in food and beverages. Application of the Quranic concept will ensure the hoteliers to serve halalan tayyiban food and beverages which it should be the primary concern of hotels to attract more Muslim customers in particular. With respect to this concern, inspections to hotel kitchens were conducted by the Department of Islamic Development Malaysia (JAKIM) which has been given the authority to issue halal status for food and beverages in hotels by issuance of halal certification in ensuring that the halal related activities are compliance to Shariah principles and its requirements.

Basically, hotel kitchens comprise western kitchen, butchery kitchen, Chinese kitchen, pastry kitchen, Malay kitchen and Indian kitchen (Rosmawati Mohamad Rasit, 2018). Currently, the halal certification in Malaysia is given to the kitchen only at the hotel premise where it shows that the implementation of halal in Malaysia does not cater the whole activities involved in the hotels. Inspection in these kitchens is to ensure that halalan tayyiban food and beverages are served. In this regard, the Quran contains many verses related to halalan tayyiban which can be applied to identify the halal tayyiban status of food and beverages. The Quranic principles provide guidelines to identify which food and beverage as permissible (halal) and prohibited (haram) for consumption by Muslims.

In relation to this matter, the Quranic concept is not only stressed on permissibility but also goodness (tayyiban) which refers to clean, pure, safe, harmless and high quality (Safiah Sidek, 2015). Thus, it is important to note that the parties concerned in serving food and beverages have to understand the Quranic concept of halalan tayibban and then to practically apply and comply with this concept in the forms of procedures and Shariah 
standards so as to ensure the halalan tayibban status of food and beverages in the hospitality sector remained followed accordingly.

The Quran has specifically guided the Muslims in deciding which food and beverages to be consumed. Halal food and beverages served in hotels are determined based on the issuance of halal certificate by JAKIM involving inspection of hotel kitchens applying several shariah standards by JAKIM officials. There are various reports on the issues of fraud in the halal food. This indicates that responsible authorities have to conduct inspections of halalan tayyiban procedures and shariah standards to premises or hotel kitchens to determine serving of halal food and beverages (Rosmawati Mohamad Rasit, 2018).

The reasons of failure to acquire halal certification could be sources of animal and plant-based food and beverage are not halal, slaughtering of halal and non-halal animals are together, food and beverage processing not complying with halal regulation, food and beverages storage, equipment, and other materials used not separated with non-halal materials (Zakiah Samori \& Noorsalwati, 2013). Thus, these elements must be put as priority and critical, hence, it must be implemented in ensuring that there is nonhalal contamination could be triggered during the preparing of halal food and beverages at the hotels.

For large hotels, such as five-star hotels, they have various types of kitchens such as western kitchen, butchery kitchen, banquet kitchen, Chinese kitchen, Malay kitchen, Indian kitchen and pastry kitchen. These kitchens should comply with halalan tayibban procedures and shariah standards to acquire halal certification and maintain their status of halal as well. However, hotel kitchens are not consistent in complying the procedures and shariah standards of JAKIM in producing halal tayibban food and beverages. Enforcement of Syariah-compliance kitchen should be carried out from time to time. On the whole, the issues of manipulation of halalan tayibban food and beverages show weaknesses in monitoring to determine halalan tayibban food and beverages in Malaysian hotels. This study aimed to examine the Quranic principles of halalan tayyiban underlying the formulating of the concept of halalan tayyiban in determining halal food and beverages at hotels in Malaysia and also to analyse to what extent that these principles be applied in food and beverage in the Malaysia hospitality sector. 


\section{METHODOLOGY}

The study adopted library research and interviews for data collection. Through library studies, selected Quranic verses and their interpretations by Islamic scholars and authors in books, journal articles related to the research topic were examined to formulate the Quranic concept of halalan tayyiban of food and beverages. A document analysis was done on the list of hotels which applied to JAKIM for the halal certification. The list showed the halal status of food and beverages for 482 hotels based on the inspection of their various kitchens by JAKIM officials. The data has been analysed by descriptive data using percentages. Unstructured interviews with one hospitality skills trainer was conducted to have holistic picture of the various kitchens in hotels that are qualified to be identified as serving halalan tayibban food and beverages.

\section{LITERATURE REVIEW}

\section{Concept of Halalan Tayyiban in al-Quran}

In Islam, it is compulsory for every Muslims to consume halal (lawful) food and beverages. In Surah al Baqarah verse 172 states that:

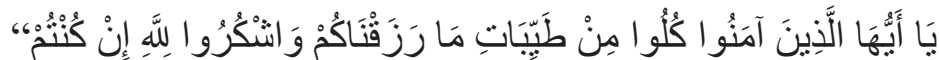

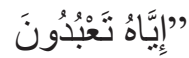

Meaning: O ye who believe! Eat of the good things that We have provided for you, and be grateful to God, if it is Him ye worship

The Quranic verse explicitly implies that food and beverages should not only be halal (permissible) but also be of good quality in terms of the necessary minerals and vitamins required by human body. The verse mentioned "to be grateful to God" is also implying that halal and good quality food and beverages not only ensure physical benefits but also spiritually benefits that will increase in ones taqwa (God-fearing) and syukur (Gratefulness) to Allah (Yunus A.B.M, 2010). 
The concept of halalan tayyiban is basically a combination of the elements of halal and the tayyib. The two main words underlying the concept of halalan tayibban are halal and haram. The word halal means permissible, allowable, permitted, not prohibited, lawful and legal (Jayyib S.A, 1998). Whilst, the word haram, which is the antonym of halal, is defined as something that should be avoided and committing it is sinful and immoral (Ibn Hazm, 1983). The term tayyib means good, pure and uncontaminated (Ibn Manzur 2003). It also has the same meaning of halal, beneficial to the human body and not harmful to human mind and soul (Ibn Kathir, 2016).

According to Yunus et. al ( 2010), haram food could be superior in quality but the consumption of it could lead to bad or unscrupulous behaviour and cause unwarranted effect in this world and the Hereafter as the Prophet Muhammad said: "and all that flesh which has grown from haram, the fire (of hell) is more worthy of it" (Hadith reported by Jabir RA (Ahmad, Darimi, Baihaqi). They further emphasized that the value of lawfulness (halal) or unlawfulness (haram) of a matter cannot be judged in isolation but must take into account the process of production, manners and ways of consumption and its effect.

The term halalan tayyiban, is expressed in four Quranic verses where the word halal and tayyib have been mentioned repeatedly as follows:

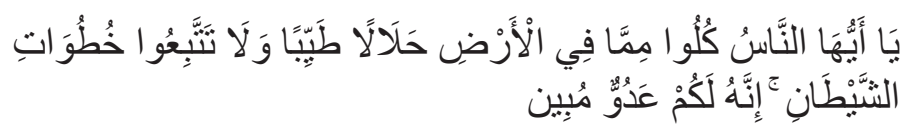

Meaning: $\mathrm{O}$ mankind eat from whatever is on earth (that is) lawful and good and do not follow the footsteps of Satan. Indeed, he is to you a clear enemy

(Al-Baqarah: 168)

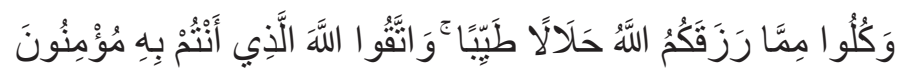

Meaning: And eat of what Allah has provided for you (which is) lawful and good. And fear Allah, in whom you are believers. 


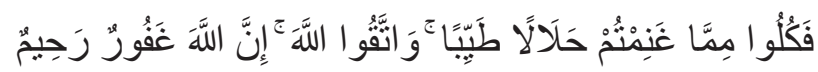

Meaning: So, consume what you have taken of war booty (as being) lawful and good, and fear Allah is Forgiving

(Al-Anfal: 69)

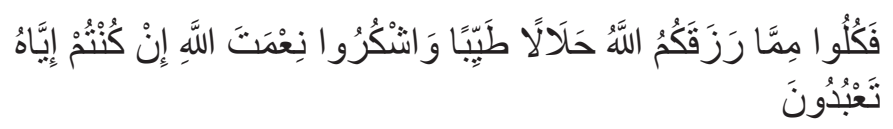

Meaning: Then eat of what Allah has provided for you (which is) lawful and good. And be grateful for the favour of Allah, if it is (indeed) Him that you worship.

(Al-Nahl: 114)

Thus, halalan tayyiban food and beverages are of two criteria. Firstly, they are lawful (halal), and secondly of good quality (tayyib) that is beneficial physically and spiritually. Safiah Sidek and Sazelin Arif (Safiah Sidek, 2015), pointed out that the procedures and shariah standard to determine halal food used by JAKIM are consistent with the concept of halalan tayyiban. However, they urged that JAKIM should conduct more vigorously in its inspection at targeted premises to apply these procedures and shariah standard. This is no exception to the hospitality sector namely hotel kitchens preparing and serving food and beverages.

\section{Application of Concept Halalan Tayyiban of Hotel Kitchen}

Zakiah Samori and Noorsalwati Sabtu (2013) stated that there is a growing interest in new tourism concept such as "Islamic tourism" or "Halal Hospitality" which applied similar concept of halal food. As a result, there has been a significant growth in the hotel industry where a large number of Muslim tourists from the middle east countries visit Malaysia each year. Thus, many initiatives are implemented to offer hotel facilities including serving food and beverages in accordance to the Shariah.

Many people understood that the food and beverages are halal as long as they do not contain pork and liquor. However, in Islam, the lawful (halal) status is not judged based on its characteristics or ingredients alone. Certain 
food and beverages maybe halal but become haram due to external factors, for example halal food and beverages become haram when preservatives, colouring and flavouring which are prohibited by shariah contain harm and defect that cannot be removed (Yunus A.B.M, 2010).

Rosmawati and Salasilah (2018) stated that halal and non-halal food preparation requires separate kitchens. Zakiah Samori and Fadilah (2013) stated that the criteria used to determine halal kitchens sources of halal food and drinks should be halal animal and plant-based. While in product storage, display and serving for instance equipment, machineries and other materials used must be made of halal materials.

Thus, the concept of halalan tayyiban of food and beverages takes into consideration of the halal definitions according to the Shariah and the tayyib definitions related to physical benefits of the human body and spiritual benefits of the human mind and soul. The application of the Quranic concept of halalan tayyiban to determine halal food and beverages at hotel is to ensure that the chain supply of them from manufacturing, storing, processing and preparing must be shariah-compliant (Rosmawati Mohamad Rasit, 2018).

\section{FINDINGS AND DISCUSSION}

Based on the analysis towards related Quranic verses and hadiths, literatures and past researches, the Quranic concept of halalan tayyiban of food and beverages is formulated. This Quranic concept of halalan tayyiban of food and beverages is based on the Islamic principles of halal and haram, taking into consideration the various halal and tayyib definitions according to the Shariah law. Halalan tayyiban food and beverages are mostly permissible, permitted and allowed by Shariah, mentioned as mubah in Arabic, and have physical benefits to the human body and spiritual benefits of the human mind and soul. Pursuant to this, the application of the Quranic concept of halalan tayyiban to determine halal food and beverages at hotels aimed to ensure that the food supply chain from manufacturing, storing, processing and preparing be adhered to the Shariah principles and its requirement.

The study found that there are inspections made by JAKIM at hotel kitchen whereby the results have shown that the inspection of kitchens in 
482 hotels (under JAKIM supervision) in Malaysia indicated that $96 \%$ of them have been given certification and valid from 2017 to 2020 . The other $4 \%$ of the hotel have their halal certification taken away and hold up for various reasons such as not abiding the Syariah standards. Based on the Manual of Halal Certification Procedure 2014, there are specific reasons on the suspension and withdrawal by the JAKIM, and the offences are categorised based on the severity as follows.

"10.4 Category of Offences and Actions

\subsubsection{Minor Offence}

$i$. Technical offence which can be given warning by the Inspection Officer for the corrective action:

a. premise cleanliness;

b. equipments' cleanliness;

c. workers'hygiene;

d. environmental cleanliness;

e. pest control;

f. other offences related to hygiene and sanitation;

g. food handler who does not have anti-Typhoid vaccination;

h. failured to produce documents requested by the inspection officer; and

i. changes and additions of raw material manufacturers which has halal certification. Manufacturers continue production without informing in writing to JAKIM/MAIN/ JAIN.

ii. Action:

a. a copy of the Malaysia Halal Certification Monitoring Notice (Notis Pemantauan Pensijilan Halal Malaysia) and NonConformance Notice (Notis Ketidakakuran Pensijilan Halal Malaysia) will be issued.

b. warning for immediate remedial action or within 14 days or any duration deems relevant;

c. Inspection Officer conduct follow-up inspection after the due date (if necessary). If the company failed to do the corrective action within the stipulated time, Notice of Malaysia Halal Certificate Suspension (Notis Penggantungan/Penarikan Sijil Pengesahan 
Halal Malaysia) will be issued and the halal certificate will be suspended; and

d. the status of the suspended halal certificate will be determined by the Halal Certification Panel.

10.4.2 Major Offence

$i$. Technical offence which can lead to suspension of the Malaysia Halal Certificate by the inspection officer and need to be presented to the Halal Certification Panel for the final decision.

a. changed/ additional supplier/ producer which does not obtain halal certification from JAKIM/ MAIN/ JAIN;

b. changed/ additional supplier/ producer which does not obtain halal certification from a recognized halal certification body overseas;

c. using Malaysia Halal Logo on products which are not certified;

d. forged halal certificate or misuse of Malaysia Halal Logo;

g. change or add to the ingredients which have been declared in the application form without written consent from JAKIM/ MAIN/ JAIN;

h. None or not enough Muslim worker in the processing areal kitchen as required in the procedure;

i. use and display of expired Halal certificate;

j. tools/ elements of religious worship are placed in the processing area/ kitchen;

k. does not comply to any related Malaysia halal standard; and

l. failured to comply with corrective action for minor offence.

ii. Action:

a. Malaysia Halal Certificate shall be suspended;

b. Malaysia Halal Certification Monitoring Notice (Notis Pemantauan Pensijilan Halal Malaysia), Malaysia Halal Certification Non Confirmance Notice (Notis Ketidakakuran Pensijilan Halal Malaysia) and Notice of Malaysia Halal Certificate Suspension (Notis Penggantungan/ Penarikan Sijil Pengesahan Halal Malaysia) will be issued to the company; 
c. report on suspension will be presented to the Halal Certification Panel for final decision whether:

- re-inspection is required; or

- the halal certificate will be returned; or

- the halal certificate will be revoked.

d. if a company failed to comply to corrective action by the Halal Certification Panel, the halalcertificate will be revoked; and

e. JAKIM/ JAIN may list down companies with suspended halal certificate in the halal portal.

10.4.3 Serious Offence

i. Offences which involves Syariah and Technical matters which lead to revocation of the Malaysia Halal Certificate by the inspection officer and need to be presented to the Halal Certification Panel for the final decision.

ii. Shariah offences are those offences involving Shariah laws as follows:

a. confirmation of haram status by JAKIM/ MAIN/ JAIN/ other Islamic authority agencies on product/ ingredient/ equipment and other miscellaneous;

b. using haram material after receiving Malaysia Halal Certificate;

c. mixing/storage of halal and haram material together;

d. storage of halal product with haram product;

e. equipments used are interchangeable between halal and haram;

f. processing of improper slaughtered or improper dead animal; and

g. use of stunner which may cause death of animal or hayat mazboh.

iii. Technical offence is an offence which does not involve Islamic laws, as follows:

a. relocation of premise/ factory without informing JAKIM/MAIN/ JAIN;

b. change of management and name of company without informing JAKIM/MAIN/JAIN;

c. unauthorized slaughtermen and the halal checker;

d. stunning for animals is not in accordance with the requirement of the standard; 
e. the stunner is controlled by a non-Muslim worker;

$f$. bringing in haram material into the premise or company which holds Malaysia Halal Certificate; and

g. using prohibited material which are in forced under the Food Act and related laws.

iv. Action

a. the Halal certificate shall be revoked immediately;

b. notices on monitoring and revocation of halal certificatewill be issued to the company;

c. report on revocation of halal certificate will be presented to the Halal Certification Panel for the final decision;

d. JAKIM/MAIN/ JAIN may list out the companies which have their certificates revoked in its halal portal; and

$e$. in the case of any outlet having its halal certificate being revoked due to serious offence, halal certificates from all other outlets shall also be revoked." (JAKIM, 2014).

In view of this matter, the inspection does not only focus on the merely halal, but hygiene and risk of food safety are also included in ensuring that food chains involved in the various kitchens, particularly the banquet kitchen, pastry kitchen, and coffee and tea kitchen following the requirements as prescribed by JAKIM.

In-depth interview was made with one informant, Mohd Zoolhilmi Musa, who is a hospitality expert recognised by the Malaysian Government. Verily, the interview has achieved insightful results on the applications of Quranic concept of halalan tayyiban to determine halalness of food and beverages at the hotel kitchens. According to the informant, even though some of the hotels have separated kitchens of halal and non-halal, the processing stage (mise-em place) before operations for cooking probability may not comply to the halal procedures and standards. For example, the pastry kitchen may use halal materials but use non-halal colouring, flavouring, gelatine, tasting, seasoning and sauces. Chaudry, M. M., Jackson, M. A., Hussaini, M. M., \& Riaz, M. N. (2000) further mentioned that all of these ingredients used as a hidden whereby it is regarded as a potentially questionable ingredient. Similar to the halal beverage served in hotels, it may not have alcohol but non-halal ingredients such as for flavouring, 
tasting and colouring may be added in the beverages needed. It is important to ensure that there is no element of pig and its derivatives as well as the alcohol-based products could be used in the processing of the halal food.

Moreover, the failure of the kitchens to serve halal food and beverages in hotel is due to issue of cross-contamination between the equipment and utensils used directly with the halal food and beverages processing. The informant further clarified that the issue of cross contamination in the events of huge capacity usage could happen when the equipment of raw material such as flatware, glassware, crockery, and silverware for the banquet are of the same for halal and non- halal. In relation to this matter, it is already against the governance of Quranic principles like what has been stated in the specific clause in the MS1500:2009 clause 3.3.1 Devices, utensils, machines and processing aids used for processing halal food shall be designed and constructed to facilitate cleaning and shall not be made of or contain any materials that are decreed as najs by Shariah law and shall be used only for ha/al food. Thus, if the food used similar equipment and utensils with the non-halal food, the status of the food becomes mutannajis (contaminated with filth) where that it is not fit for consumption for the Muslims. There is a need for a proper monitoring control on the equipment and utensils used for preparing the food especially food served at the hotel since the certification of halal is only for the specific hotel kitchen that are dedicated purposely for the halal food preparation. Thus, the chain-supply of producing halalan tayyiban food and beverages throughout from manufacturing and to the plate of the customers must be halal, pure, clean, and not harmful physically and spiritually.

Furthermore, the three-star and four-star hotels in Malaysia are mostly Muslim customers friendly. Generally, their kitchen fulfilled the procedures and Shariah standards of JAKIM and these hotels are granted with the halal certification. However, the 5-star hotels which provide more comfortable and exclusive services have become the favourite choice for large customers including non-Muslims. The problem of this huge hotel is that they do not label food and beverages that have added with non-halal ingredients which make the food and beverages are not halal to be consumed by Muslims. This has raised confusion between halal and non-halal food and beverages for the Muslim customers (Mohd Zoohilmi Musa, 2019). 
In a nutshell, it is important to the hospitality sector to understand the Quranic concept of halalan tayyibban clearly. This could be realized by embedding the concept into practice where the hoteliers have to ensure the halal requirements from the halal authorities are followed accordingly. Indeed, this could increase the level of halal integrity in the hospitality sector and the Muslim could access the food and beverages that are accurately halalan tayyibban.

\section{CONCLUSION}

The Quranic principles of halalan tayyiban in the study are based on the Quranic verses of al Baqarah (2) verses 168, al Maidah (5) verse 88, Al Anfal (8) verses 69 and Nahl (16 verses 114: and interpretation of the Muslim scholars. In a nutshell, the food and beverages served at hotels should not only be halal that is permissible, permitted or lawful, but also tayyib that is of good quality which is beneficial physically (to human body) and spiritually (to human mind and soul). Thus, halalan food and beverages are good and pure in quality because it is halal. Besides their halal status, they should be of nutritious and good taste and smell, clean and fresh, pure, beneficial to body, mind, and soul.

To have an effective application of the Quranic concept of halalan tayyiban and to determine halal food and beverages at hotel, there should be a clear understanding by food managers and operators, and practitioners on the Quranic concept of halalan tayyiban in manufacturing, preparing, processing, storing and serving food and beverages. Besides that, there should be timely enforcement and monitoring by responsible authorities or bodies to ensure that hotels with halal certification are consistent in abiding by the halalan tayibban procedures and Shariah standards in continuously providing halal food and beverages to the Muslim customers at the hotels.

\section{ACKNOWLEDGEMENTS}

The authors would like to thank the Academy of Contemporary of Islamic Studies of Universiti Teknologi MARA for giving full support to this study. 
Journal of Contemporary Islamic Studies

\section{REFERENCES}

Chaudry, M. M., Jackson, M. A., Hussaini, M. M., \& Riaz, M. N. (2000). Halal Industrial Production Standards. Illinois: J\&M Food Products Company, 1-15.

Ibn Hazm, (1983). Al-Ihkam fi Usul al-Ahkam, vol 3, Beirut, Dar al-Afaq al-Jadidah

Ibn Kathir, (2016). H.: A compilation of the Abridged Tafsir Ibn Kathir. Volumes 1-10.

Ibn Manzūr, (2003). Lisān al- 'Arab. Qāhirah: Dār al-Hadīth, 7, 705.

Interview on 22 February 2019 with Mohd Zoohilmi Musa, an hospitality expert of Malaysia recognised by the Ministry of Human Resource of Malaysia, the Head of Department of City Advance Skills Academy at Kuala Lumpur.

Jayyib, S. A, (1998). Al-Qamus al-Fiqhi Lughatan wa Istilahan, Beirut: Dar al-Fikr.

Manual Prosedur Persijilan Halal Malaysia (2014). Jabatan Kemajuan Islam Malaysia (JAKIM), semakan ketiga, Firdaus Press: Pusat Pentadbiran Kerajaan Persekutuan, Putrajaya.

Mohamad, (1993). Islamic Dietary Concepts and Practises, Chicago: The Islamic Food and Nutrition Council of America (IFANCA).

MS 1500:2009, Halal Food Production, Preparation, Handling and Storage General Guidelines (Second Revision). https://law.resource.org/pub/ $\mathrm{my} / \mathrm{ibr} / \mathrm{ms} .1500 .2009 . \mathrm{pdf}$

Rosmawati Mohamad Rasit \& Salasiah Hanin Hamjah, (2018). Provision of Shariah-Compliant Hotel Services Towards Muslim Tourism in Malaysia, International Journal of Civil Engineering and Technology, vol 9, issue 9. 
Safiah Sidek \& Sazelin Arif, (2015). Application of Halalan Tayyiban in the Standard Reference for Determining Malaysian Halal Food, Asian Social Science, Published by Canadian Center of Science and Education, vol 11, no 17.

Siti Radhiah Omar \& M. Shahrim, (2013). Halalan Toyyiban: Perspektif Isu Logo Halal, Institut Penyelidikan Produk Halal, Serdang: Universiti Putra Malaysia.

Yunus, A. B. M., Wan Chik, W. M. Y. B. \& Mohamad, M. B (2010). The Concept of Halalan Tayyiba and Its Application in Products Marketing: A Case Study at Sabasun HyperRuncit Kuala Terengganu, Malaysia. International Journal of Business and Social Science, 1(3), 239-248.

Zakiah Samori \& Fadilah Abd Rahman, (2013). Establishing Shariah Compliant Hotel in Malaysia: Identifying Opportunities, Exploring Challenges, West East Journal of Social Sciences, vol 2, no 2.

Zakiah Samori \& Noorsalwati Sabtu, (2013). Developing Halal Standard for Malaysian Hotel Industry: An Exploratory Study, Procedia-Social and Behavioral Science, published by Elsevier Ltd, Centre for Islamic Thought and Understanding, Universiti Teknologi MARA. 
